\title{
Osemdeset let akademika PROF. DR. IGORJA VRIŠERJA
}

$\mathrm{Ob}$ petisedemdesetletnici akademika prof. dr. Igorja Vrišerja je Oddelek za geografijo Filozofske fakultete Univerze v Ljubljani izdal štiriindvajseto številko revije Dela z naslovom Regionalno planiranje in regionalni razvoj med teorijo in prakso. $\mathrm{V}$ njej je sedemnajst avtorjev $\mathrm{z}$ različnih strokovnih vidikov predstavilo teoretske, metodološke, vsebinske in praktične razsežnosti regionalnega planiranja ter izpostavilo nekatera odprta vprašanja sodobnega regionalnega razvoja v Sloveniji. Torej tiste vsebine, ki so bile vedno predmet dolgoletnega uspešnega znanstvenega in strokov-

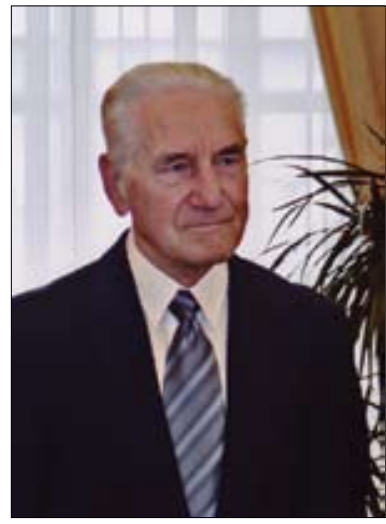
nega preučevanja, ter ne nazadnje tudi univerzitetnega pedagoškega dela akademika prof. dr. Igorja Vrišerja. In kot sem zapisal že ob njegovi sedemdesetletnici v Geografskem vestniku (GV 72-1), utemeljitelja ljubljanske 'geografske regionalne planerska šole', ki jo je zasnoval na temeljih aplikacije geografskega koncepta predvsem na področju številnih geografskih analiz poselitvenega in urbanega sistema, industrializacije, ekonomskogeografskih regionalizacij in vrednotenj družbenogeografskih in prostorskih vplivov ter posledic regionalnega razvoja v Sloveniji.

Med temi vsebinskimi področji je akademik prof. dr. Igor Vrišer posvečal posebno pozornost teoretskim, metodološkim in vsebinskim vprašanjem sistema poselitve oziroma urbanega sistema. Razsežnost tega njegovega obsežnega znanstvenoraziskovalnega in strokovnega dela se je odražala in se odraža še danes v vseh temeljnih razvojnih usmeritvah Slovenije. V drugi polovici šestdesetih let je akademik prof. dr. Igor Vrišer opredelil urbano omrežje in centralne kraje v etničnem prostoru Slovenije, v začetku sedemdesetih let pa je pripravil študijo o vplivnih območjih slovenskih mest. Rezultati omenjenih in nekaterih drugih temeljnih raziskav so bili objavljeni v kartografskem dokumentacjskem gradivu o stanju v prostoru in razvojnih težnjah (Zavod SR Slovenije za regionalno prostorsko planiranje, 1970) ter v gradivu o urbanem sistemu, kjer so bile prikazane tri variante policentričnega urbanega razvoja Slovenije. Na tej podlagi so bila sprejeta stališča o izboru ene izmed variant urbanega sistema: policentrični urbani sistem.

Koncept policentričnega urbanega sistema je tako postal del splošne zasnove regionalnega razvoja Slovenije. Izhodišča in temelji za politiko regionalnega razvoja (Zavod SR Slovenije za regionalno prostorsko planiranje, 1973) so postali prvi razvojni dokument, ki ga je leta 1973 sprejela Skupščina SR Slovenije kot prvi temelj regionalne politike razvoja in urejanje prostora. V njem je med tremi poglavitnimi smotri opredeljen tudi »policentrični urbani sistem, ki bo kot zavestna odločitev za bolj uravnoteženo prostorsko razporeditev stanovanj in delovnih mest s posebnim poudarkom na porazdelitvi centralnih funkcij (terciarnih in kvartarnih dejavnosti) omogočal policentrični razvoj.« V zasnovi urbanizacije (Zavod SR Slovenije za regionalno prostorsko planiranje, 1974) kot elementu regionalnega prostorskega plana, so bili prikazani rezultati obsežnih raziskav akademika prof. dr. Igorja Vrišerja o vplivnih območij slovenskih mest na zgornji, srednji in spodnji stopnji oskrbe. Ta strokovna 
izhodišča so bila podlaga za opredelitev pvih študijsko-planskih regij v Sloveniji. Med leti 1975-1977 so nastala strokovna gradiva z naslovom Zasnova uporabe prostora, ki so bila leta 1977, skupaj s poglavji o ekonomsko-socialnemu razvoju, industrializaciji in urbanizaciji, predstavljena v obliki delavnega gradiva z naslovom Sinteza, Povzetki strokovnih gradiv, ki zadevajo prostorski plan Slovenije (Zavod SR Slovenije za družbeno planiranje, 1977).

Policentrični urbani sistem oziroma policentrični koncept razvoja je postal tudi temeljna razvojna usmeritev za celotno poselitev Slovenije v tako imenovanih prostorskih sestavinah dolgoročnega družbenega plana Slovenije do leta 2000 (UL SRS 1/86) ter za ohranjanje poselitve na celotnem območju Slovenije kot elementu spodbujanja skladnega regionanega razvoja (UL RS 60/99) ter eden izmed ciljev prostorskega razvoja Slovenije - razvoj policentričnega omrežja mest in drugih naselij - v strategiji prostorskega razvoja Slovenije (Ministrstvo za okolje, prostor in energijo, 2004). In ne nazadnje je bil policentrični razvojni koncept $\mathrm{v}$ obliki zasnove mest po načelu policentričnega razvoja prepoznan kot temeljna razvojna prednosti Slovenije v strategiji gospodarskega in strategiji regionalnega razvoja (DRP RS 2007-2013, Vlada RS, 2008).

Akademik prof. dr. Igor Vrišer je s tem svojim znanstvenoraziskovalnim in strokovnim delom ter ob ustvarjalnem sodelovanju $\mathrm{z}$ drugimi sodelavci in strokami, pomembneje prispeval k snovanju strokovnih temeljev in izhodišč pri zasnovi regionalne, prostorske in razvojne politike Slovenije. 